\title{
MILESTONES IN THE MAKING OF THE THIRD WORLD: A HISTORICAL EXPOSITION
}

VENATUS V. KAKWAGH

(Received 18 June 2021, Revision Accepted 5 July 2021)

\begin{abstract}
Before the $18^{\text {th }}$ century, the word was not categorized in any form but just the universe. This exposition has however shown that from the $18^{\text {th }}$ century, certain events in Europe led to the categorization of the world into a two-world order as first and second (civilized vs. primitive) and later into a three-world order as $1^{\text {st }}, 2^{\text {nd }}$ and $3^{\text {rd }}$ world. The exposition has identified the milestones that led to this categorization as colonialism, neo-colonialism, imperialism and ideological war (cold war). The exposition has noted that due to the collapse of the Soviet bloc, the world was pushed back to a dualistic status- North and South. However, as the North and South dialogue was gaining momentum, globalization came onto the scene and pushed the world back to a one-world order- the global village.
\end{abstract}

KEYWORDS: Milestones; Third Word; Colonialism; Neo-colonialism; Profile; Poverty; Civil Society; Imperialism; Globalization.

\section{INTRODUCTION}

The term 'third world' is a reference to countries of Africa, Asia and Latin America. The term has been extensively employed by scholars because of the wide spread acceptability it gained (Muni, 1979). From the early 1960 s, the term was used as a synonym for such phrases as underdeveloped world, developing world, less developed countries, former colonies (Muni, 1979). In other words, the term has often been used as shorthand for poor or developing nations. If the term "third world" has been widely accepted and extensively used by scholars then, what are the milestones that led to its making? This question forms the basis for this write-up. It is therefore important to first highlight the role played by colonialism, neo-colonialism and imperialism. The paper also $\mathrm{x}$-rays the profile of third world countries. The paper intends to explain the reasons behind the shift from a threeworld-structure to a dualistic status and finally to the present global village state.

Colonialism and the Third World
The making of the third world was greatly influenced by the process of colonialism. Colonialism is a process whereby a foreign power or country subordinates another country in terms of geography, social, economic, political, cultural dimensions. It is a practice by which a powerful country directly controls less powerful countries and uses their resources to increase its own power and wealth (Horvath, 1972; Longley, 2021). Historically, colonialism occurred when the ancient empires such as the Roman Empire, Mali Empire, and Songhai Empire etc conquered other territories to extend their geographical land mark and to extract revenue.

In Europe, colonialism started around the $16^{\text {th }}$ century. This process greatly facilitated Europe to subjugate and have scattered regions across the globe especially in Africa, Asia and Latin America. The reason that propelled European countries to take on the added responsibility of governing other people was closely linked to the economic factor. Colonialism arose in Europe

Venatus V. Kakwagh, Department of sociology, Kogi State University, Anyigba- Nigeria 
because of fundamental developments. First, the European society had transformed from the peasant agriculture to the mechanized agriculture. This agricultural revolution produced agricultural capitalist class. The revolution of agriculture also produced merchant capitalist class. Also, around the $19^{\text {th }}$ century, there was a generalized industrial revolution in Europe which produced industrial capitalist and subsequently finance capitalists

of all these revolutions, the one that most facilitated the process of colonialism was the industrial revolution. The revolution of industry from small family cottage industry based only in England specifically Manchester to a generalized industrialization in Europe created a compelling need for raw materials and markets. The intense search for raw materials and markets by the manufacturers meant that free trade could not be guaranteed. There was therefore a movement away from free trade to captive trade to ensure availability of raw materials and markets to sell. Thus European countries like Britain, Portugal, France, began to capture other territories. This economic factor later expanded to the political factor. This was chiefly to ensure territorial identity and the maintenance of law and order to ensure that the subjugated people did not revolt.

Colonialism came to the people of Africa, Asia and Latin America through four processes namely; the search, the scramble, partitioning and the consolidation. The search was preceded by explorers such as Mungo Park and the Lander brothers in search of raw materials. As the demand for raw materials intensified in Europe, so also was the search for them intensified in the colonies. This intensified search led to more serious scramble to control more territories. Thus, by 1884 in Berlin, the countries of Africa, Asia and Latin America were partitioned and given to several countries of Europe (Faal, 2009). For the European societies to establish or consolidate their stronghold on the colonies, they had to establish different social, economic, political structures. They also introduced cultural elements such as language, dress, and values. This completely disintegrated the pre-existing traditional values and cultures (Igboin, 2011).

Implicitly, colonialism led to the creation of two worlds- the civilized and the primitive or core and periphery. While colonialism led to the development of the core, it created underdevelopment of the colonized countries

(Rodney, 1972). Within the colonies, colonialism created two hostile classes of people namely; the working class and the elite class. By creating two set of classes, colonialism created problems within itself. There was increasing restiveness by the working class and the elites. The working class saw themselves in conditions of double exploitation both in terms of race and class. Colonialism created an elitist class with life styles different from and above others within the colonies but as compared to the colonialists, they were inferior.

Due to the tensions and contradictions, there were increasing social, and political unrest. These tensions planted the seeds for the mechanisms whereby indigenous groups made of youths, elites and the working class rose up to challenge colonial rule. It was on the spring board of nationalism that the whole historical process of decolonization began. Nationalists began to exult pre-existing traditional values that were attacked and destroyed by the imposition of foreign rule and the need to restore them. Thus, across the continent of Africa, nationalists began to call the people to realise that they had values before the imposition of colonial rule. The activities of the nationalists led to constitutional reforms and organisation of political parties to fight colonization (Olasupo, et al 2017).

The collapse of colonization led to the emergence of nations after independence. Although the European colonies in Africa, Latin America and Asia had fundamental social, economic, political, and cultural differences before the imposition of colonial rule, the countries began to exhibit similar economic, social, political, cultural characteristics when they emerged as nations at independence. The similarity of these countries that were geographically far flung apart became possible for intellectuals to ideologically coin the term 'Third World' for them.

\section{DECOLONIZATION}

Decolonization is a process by which colonies became independent of the colonizing countries. Decolonization was gradual and peaceful for some British colonies largely settled by expatriates but violent for others. For example, while some countries like Cuba, Vietnam, Indonesia, Algeria took the Marxist revolutionary tenets led by radical elites to fight colonization, Nigeria and the conservative India led by radical but non-violent Ghandi took the peaceful approach of constitutional reforms which led to India attaining independence in 1946 and Nigeria in 1960.

It should be pointed out that decolonization itself did not end colonialism because apart from the 
attainment of political or flag independence, new forms of colonialism much more powerful than the political emerged- neo-colonialism. All nations that became too independent-minded experienced series of coups.

Neo-colonialism touches on the culture of the people. It is the colonization of the personality. It does not occupy geographical space but personality. The individual becomes baptized in the values, aspirations of the colonial masters (Igboin, 2011). Neo-colonialism socialized people to see themselves and their society from the point of view of the west. Neo-colonialism is therefore a process of portraying the west as superior both in terms of mass culture (cultural imperialism), intellect, and psychology (Rahaman,et al 2017).

Politically, new forms of colonialism also emerged. For instance, at independence, flags and anthems and fashion changed but economic and cultural imperialism continued. There were new forms of economic control by foreign powers. One of the most important forms of economic imperialism was the emergence of multinational corporations like John Holt, UAC, Leventis, etc. These became the strongholds both in economic and political environments. The economic stronghold was strengthened by borrowing (debt) which became the only source of financing projects. Borrowing became a condition for development with harsh terms by the international monetary institutions such as World Bank and the International Monetary Fund (IMF) (Nkwocha, 2008). The conditionalities were entrenched commonly among the third world countries. Instead of collateral, the IMF demand reforms such as economic reforms, political reforms, deregulation. The highest form of neocolonialism is imperialism.

\section{IMPERIALISM AND THE THIRD WORLD}

Imperialism is a global system of the evolution and development of hegemonic control of social, economic, political, and cultural values and practices of one country by another either by coercion or persuasion (Longley, 2020). According to Lenin, it is the highest form of capitalism. Imperialism functioned in a way that led to the creation of three worlds. Imperialism was fuelled by ideology. After the Second World War (WW II), there were certain ideological developments especially the cold war in Western Europe (the West) which came to embrace and include North America. The cold war therefore set the stage for the emergence of imperialism and for that matter, the three worlds.
After the Second World War, there was the emergence of a global bourgeoisie as agricultural, merchant, and industrial and finance capitalist classes. These bourgeois classes were all located in the West but operated globally in Africa, Asia and Latin America. Scholars have generally maintained that there were two stages that led to the emergence of the three words namely; (a) the installation stage and (b) the post World War II. The first phase (installation) which began in the early $20^{\text {th }}$ century through the process of colonization was marked by resistant accommodation. In other words, though nationalists resisted colonialism, they accepted colonial structures. The second phase was characterised by the rise of the United States to prominence. In the first phase Britain was the only industrialized nation. But after WW II, the British Empires began to collapse. While Britain was losing control over her colonies, America was rising and arriving on the scene and was increasingly becoming a colonial power though it never colonized any territory. Also the arrival of Russia on the scene created added dynamics.

The arrival of the Soviet Union which distinguished itself from Western Europe and America and the emergence of countries of Africa, Asia and Latin America against the imperialist moves tended to create three separate worlds- the Socialist, Capitalist and the Third World. The idea of one world being $1^{\text {st }}, 2^{\text {nd }}$ was more implied than applied. While the West saw itself as the first world, the Socialist countries would not accept the status of the $2^{\text {nd }}$ world and regarded America as a devilish world characterized by capitalist ideas. The Socialist countries therefore called themselves the Soviet bloc.

The emergence of the three worlds is therefore attributed to the rise, installation and expansion of capitalism. The second world emerged on the basis of organized attack on capitalism both in theory and practice (Evan,2018). The most important personalities in the making of the second world are Karl Marx, Engels, Lenin, and Stalin. The political and economic ideas and ideologies of these people laid the foundation for the emergence of a society quite distinct from the capitalist west. Marxist's ideas led to the Bolshevik revolution, the spread of socialism, and communalism first in Eastern Europe and the establishment of socialist/communist structures (Zajda, 2014).

The socialist world sought to distance itself from the West both in terms of social, economic and political processes. Thus a new world order 
began to emerge heavily guided by critical ideas about the west. The intention was to counteract capitalist development and to oppose its expansion abroad. This aggressive posture put the Soviet bloc on a collision course with the west led by the United States.

Due to the ideological struggles, both the West and the Soviet bloc began to look for support from the peripheral countries. The refusal of the peripheral countries to join forces with either the West or the East gave rise to the unaligned movement. Thus, by 1960 s one could clearly distinguish three worlds. It was possible to find sufficient distinction between Western and Eastern Europe and there were sufficient similarities between Africa, Asia and Latin American countries. While the first and second worlds were seen in terms of differences between them, the third world was a collection of countries with cultural, economic, political and social similarities.

Since this exposition is particularly on the third world, let us have a brief understanding of the profile of third world countries.

The Profile of Third World Countries

The process of decolonization rose from the activities of the nationalists who were concerned with doing away with the pervasive nature of colonialism and the establishment of self-rule. The beginning of decolonization however coincided with the intensification of ideological rivalries in Europe and North America. This reinforced the determination of the metropolitan governments to prevent the spread of socialist/communist ideas in the colonies

To understand the profile (the inside) of third world countries depends on the type of lenses one uses. Using the sociological lenses, it could be seen that all third world countries have a common colonial experience. They themselves being ex-colonies, they have no territories to colonize. They are always looking for outside assistance to address their economic and political problems. In terms of culture, third world countries are culturally and socially developed but economically and technologically undeveloped. Most of the countries are still traditional societies. While others have transited from traditional to socialism, others have transited from traditional to capitalism and yet others transited from capitalism to socialism

Much of the $20^{\text {th }}$ century saw most of these countries struggling with two dominant cultures and came up with a triple heritage - tradition, Christianity, and Islam. Many of them such as
Algeria, Nigeria, India, etc are therefore characterized by intense religious strife.

In every society, developed or undeveloped, there is a coexistence of affluent metropolitan sector and highly impoverished rural sector. In the third world, what confronts people coming in is not poverty but affluence. However, it is when an in-depth examination of the profile of third world countries is taken that the realities of third world countries begin to manifest. All third world countries have similar characteristics. They have large families, high population growth rate, high illiteracy rates, and low earnings. They are also suppliers of primary goods and importers of large quantities of manufactured goods. They are also characterized by mixed economies- capitalism on one hand and state control on the other (Gurtner, 2010).

Third world countries share geographical and ecological impediments such as extreme heat and bacteria infestation which affect crops and very often lead to natural disaster. Politically, third world countries share attenuated independence. Their positions as independent nations are tampered with by the process of neocolonization; a process that controls not only their economies by foreign bodies but also affects their mass culture. Third world countries have common political instability. After the Second World War, political instability became a common feature of third world countries. This can be attributed to how they were put together as independent nations. This political instability often leads to coups- the takeover of leadership by the military (Ongayo, 2008) v.

Although, democracies have been put in place in most third world countries and economies revitalised, one thing still remains a dominant feature of third world countries- poverty. The prevalence of poverty has brought about the phenomenon of borrowing and aid. Borrowing has become the only source of financing development projects. However, harsh conditions for borrowing are entrenched commonly among the third world countries. They are required to make economic reforms, devaluation of national currencies, etc. This explains why issues of privatization, deregulation have become common slogans of third world countries.

\section{POVERTY}

The phenomenon of poverty has come to engage global attention. It has become of interest to both academicians, government, donor agencies and development partners. Poverty as a concept refers to the inability of a people or society to 
meet the basic essentials of life such as safe water, balanced diet, physical and mental security, appropriate clothing and shelter. These collectively enhance the well-being of an individual or group.

Poverty is measured in terms of two interrelated indices-the Gross National Product (GNP) and Per Capita Income (PCl). Poverty exists in a country that has low GNP and PCl. Poverty can also be measured in terms of life expectancy and mortality rates. The higher the life expectancy, the richer the country is. The lower the life expectancy the poorer the country is. When people live long in a country, it indicates that the country has made significant strides to overcome poverty. Also when infant and child mortality rates are high, it shows that the country is poor (Haughton \&Khander, 2009).

Poverty is therefore looked at in terms of quantitative and qualitative indices and in terms of basic needs. When the basic needs of shelter, food, and clothing cannot be met and or social services such as education, health, sanitation, transport system are not working in a society, poverty is said to exist. Poverty is a crisis because after the third world countries had emerged as independent countries, it was hoped that they would move to development. But long after independence, poverty has continued to be aggravated. Especially in countries of Africa, poverty seems to overwhelm all the attempts aimed at overcoming it. In fact, the poor themselves seem to have given up. Rather, it is those who are not poor that are getting concerned with the issue of poverty. One can therefore say that while there is deepening crisis and resignation, there is also growing interest in poverty. Several reasons account for this growing interest in poverty. These include but not limited to;

(a) Theoretically, scholars still believe that capitalism reinforces poverty. There is therefore theoretical interest in poverty; that is to prove some theoretical points.

(b) Politically, it is the interest of every government to ensure that poverty is eliminated

(c) Economically, there is local and global interest to eliminate poverty so as to create a market for both local and global products. The general argument is that the removal of poverty puts more buying power in the hands of the people. It is therefore the concern of countries of the north to ensure that poverty is eliminated. This will make countries of the south richer and more capable of buying their products. This explains the phenomenon of aid. Countries of the
North believe that for the poor countries to be able to buy their products, it is essential to aid them to take advantage of the opportunities that exist in their countries. This will raise their standard of living and increase their income. The increased income will create new life styles and values for the products of the north.

The persistence of poverty in the third world has given rise to two broad schools concerned with explaining poverty. One school believes that third world countries have opportunities which if properly harnessed and utilized will eliminate poverty and thus improve their well-being. Regrettably however, these opportunities are not properly taken advantage of because of certain attitudes and values the poor hold. Therefore the poor are to be blamed for their poverty because poverty is not an inherent thing in any society. For poverty to be eliminated, people must take advantage of the opportunities available to them by changing their attitudes and value orientations.

Another school believes that it is the structure of the society that is responsible for poverty. This school argues that the poor have the will to achieve or improve their well-being but the opportunities are slim or poorly distributed because of structural problems. The poor are willing to improve their well-being but cannot have access to the opportunities because the opportunities are monopolized by a few people. Therefore, for the poor to improve their wellbeing, society should be structured in such a way that the poor can have access to evenly distributed opportunities.

These schools affected how people interpreted poverty. However, there has emerged in recent years an anthropological approach in understanding poverty. The approach emphasizes that poverty should be understood from the point of view of the poor. This approach has affected globally the way poverty has been perceived and understood. The approach maintains that to address poverty, the poor should be involved in defining their problems, prioritising them, implementing and evaluating the intervention projects. This bottom-top approach has greatly shifted emphasis from the previous top-down approach in understanding poverty. There is thus a shift from the integrated approach to participatory approach. The participatory approach sees rural poverty as multidimensional and diverse in nature because what may be the cause of poverty in one society may not be so defined in another. The approach sees poverty as relative in cause and effect. 


\section{CIVIL SOCIETY}

After the third world countries had emerged as independent nations, they were dominated by influences of the state and the market. Particularly the market forces were controlled by foreign interest though the state still remained the dominant political influence.

This relationship between the state and the market (organized private sector) could not however adequately address the issues of poverty by providing economic and social services. The failure of the state and its dominance in collaboration with the market gave rise to serious concerns. Thus, development experts and planners began to look at the possibility of bringing another element- the civil society- into the relationship. This relationship was seen as crucial both in terms of outcomes of development and political programmes. Thus, by the late 1980s and the early 1990s attention became centred on the civil society as strong agents of social change (Jezard, 2018).

Civil society organisations refer to groups of people who come together for collective purpose. They are not under the influence of the state and the market. They are formed to correct the social ills of the market and the wrong policies of the state.

Based on the classification of the African Development Bank (AFDB, 2012) in Africa, civil society organisations are defined into four broad categories

(1) Grassroots organisations: These include parents' organisations, town development associations, age grade or groups, community development associations, youth groups, nongovernmental organisations. Because these are continually in touch with the local people, it is hoped that if they are properly supported could bring about the needed change.

(2) Intermediary level organisations: These refer to several bodies coming together to provide services to the community. They include trade unions, cooperative societies, religious bodies such as Christian Association of Nigeria (CAN), etc.

(3) Coalition and platforms: These groups come together for particular purposes. They are never permanent groups but groups of civil society organisations that come together to fight for a purpose.

(4) Specialised Organisations: These are formed out of state control to provide specialized support and services to other civil society organisations. They deal with research and policy issues and provide relevant advocacy materials for policy formulation. These organisations represent the people who are voiceless in society.

The civil society has been in existence since time immemorial. However, the civil society became a matter of serious concern when donor agencies began to deal with the issues of poverty in third world countries (Kastrati, 2016). Initial attempts by donor agencies and bilateral agencies failed because funds channelled through the state to address the problems of the poor never got to them. To avoid the hijack of these funds, donor agencies began to look for organisations that would be reliable. They found these organisations in the civil society.

It should be borne in mind that it also became obvious that the state, the market and civil society, acting independently could not bring the needed development. There is therefore a need for collaboration between the three. The concern is that civil society has good agenda but lacks the resources. The market on other hand has the resources but lacks the reach. Therefore, if civil society collaborates with the market, the market can provide the resources and learn the principles of social responsibility. Yet, this alliance has some limitation because both lack the political will (the reach).

There is also the possibility of collaboration between the state and the civil society. But here too there is the fear of domination and manipulation by the state. This fear creates tensions. Many agencies have realised these short comings between the state, market and civil society and are taking all the components on board to deal with the issues of development in the third world countries. To minimize the internal weaknesses of the three components and harmonize their strengths, donor agencies today consult with the state, market and civil society organisations before formulating policies and strategies to tackle poverty.

However, attention is increasingly being placed on the civil society for what it can do now and for the future. The civil society organisations are seen as guardians of democracy and the fundamental human rights of people. This is predicated on the fact that towards the 1990s; most third world countries had transited from military to democracy. It is therefore expected that civil society organisations should protect democracy by ensuring transparency and accountability.

In Nigeria, this role of ensuring democratic governance has been played by the civil society organisations. The southern civil society 
organisations played active roles in ensuring that democracy is installed in Nigeria. Civil society organisations in Nigeria could be involved in planning, formulation, implementation and evaluation which have been the exclusive reserve of government. In fact, in Nigeria, civil society organisations could be involved in the mobilization of the masses for popular actions against unpopular rule.

\section{NORTH- SOUTH DIALOGUE}

The dynamics of the $20^{\text {th }}$ century made it unreasonable to think of the world in terms of $1^{\text {st }}$, $2^{\text {nd }}$, and $3^{\text {rd }}$. Towards the end of the $20^{\text {th }}$ century, the second world collapsed and was merged with the first world. The collapse of the second world led to the categorization of the world in terms of North and South. It should be understood that all the countries in the north fall within the northern hemisphere while those in the south fall within the southern hemisphere.

Primarily, the north and south arrangement was an attempt to eliminate the psychology of superiority that was attached to the $1^{\text {st }}, 2^{\text {nd }}$ and $3^{\text {rd }}$ world categorization. Rather, the dualistic status was to look at the vulnerabilities of countries of the north and of the south. Countries of the south are generally poor and therefore are vulnerable to economic and development changes. They have limited functional sovereignty though they have political sovereignty and their resources are easily manipulated. Countries of the south are therefore vulnerable to economic changes in the north. Countries of the north on the other hand are affluent and generally resilient.

What connects countries of the south is the desire to individually and collectively escape poverty and to protect their interests. A dominant interest that joins countries of the north together is to have energy (oil) at minimal cost and this energy is located in the south. It should be noted that most of the machines used in the north are oil driven. Because the north lacks oil, they are vulnerable to changes in oil prices in the south.

This situation created the need for a dialogue. This became essential so as to transform the north and south from dependence through independence to interdependence. The basic reason was that it does not pay the south to remain economically dependent on the north. The south is therefore to negotiate strategic changes in the global system in such a way that the changes support fundamental development in the countries of the south.
In a nutshell, it can be said that two key issues were crucial in this dialogue- interest in oil and economic system. There was a realization by both that economic injustice was a threat to global justice. Both the north and south believed that if there was economic injustice, processes could be initiated in the south that would be harmful to the north. This concern drove closer relations between the north and the south. Both the north and the south therefore started calling for the removal of harmful trade barriers and the liberalization of trade.

However, the sensitivity of countries of the south because of colonial history saw this arrangement as a process of manipulation. It should be borne in mind that the south has always been of interest to the north because of its market potentials. But the north approaches the south with a different agenda. Thus, by 1974, the United Nations began to emphasize the need for a new world order. It was under this scenario that globalisation came.

Globalisation

Globalisation is a process as well as a philosophy. It is a process that makes the whole world more uniform and standardised. It is a process of change that embraces social, economic, political and cultural dimensions. Globalisation can therefore be said to be a multidimensional process which unfolds in multiple realms of existence simultaneously.

The history of globalisation begins with the history of the west. About the $12^{\text {th }}$ century there was no world as a social category but just the universe. But between the $13^{\text {th }}$ and $14^{\text {th }}$ centuries, there began to emerge a world order characterized in terms of civilized and noncivilized or primitive. By the $15^{\text {th }}$ and $16^{\text {th }}$ centuries, fundamental developments in Europe especially the industrial revolution led to the expansion of colonialism. The expansion of colonialism facilitated the emergence of a two world order- the core and periphery. By the $19^{\text {th }}$ century, a two-world order had clearly emergedthe developed and the underdeveloped worlds.

However, by the middle of the $20^{\text {th }}$ century, the developed world, namely; the Soviet bloc and the west including the United States, had split into two based on ideological concerns. Thus, it became possible to categorize the world in terms of $1 \mathrm{st}, 2^{\text {nd }}$ and $3^{\text {rd }}$ worlds. Again towards the end of the $20^{\text {th }}$ century, the second world had collapsed thus moving the world back to a twoworld order. This time, discourse was in terms of North and south. The collapse of the $2^{\text {nd }}$ world exposed the vulnerabilities of both the North and 
the South. While this was gaining momentum, globalisation came to the scene and pushed the world back to one-world order.

Historically, there are many modes of globalisation. These range from the cross-cultural long distance trade between Africa and countries of Europe, the introduction of slavery, colonialism, Amnesty International which is concerned with internationalising human rights standards and most recently the global panic of

\section{AIDS AND COVID-19.}

In contemporary usage, globalisation is a process which compels all countries to come together for interdependence and interrelation both in terms of economic, political, social and cultural spheres (Albrow \& King, 1990). The relationship has no regard for boundaries of all sorts. The relationship creates important economic, social, cultural, political advantages and specialisation. Socially, globalisation emphasizes that human rights should be respected and protected. Relationships between individuals and groups should be based on the rule of law. In the area of politics, the globe was traditionally seen in terms of independent nation-states defined by distinct geographical boundaries, having separate economic institutions, political systems, and cultural practices. Today however, globalisation which is a movement toward a one-world order has broken down all these boundaries.

Globalisation places emphasis on the economic factor. It emphasizes comparative advantage in terms of production. The economic factor facilitates massive flow of capital globally. This capital is located in the North and is controlled by capitalist institutions like the World Bank and the International Monetary Fund (IMF). The driving philosophy of globalisation is that of free market allowing the market forces to determine policies of production. For instance, if a country is specialised in the manufacture of finished goods or products and another is specialised in the production of raw materials, the producer of raw materials should buy from the manufacturer of finished products instead of getting involved in production. If products are produced in New York and sold in Nigeria cheaply then, there is no need for Nigeria to be involved in manufacturing the same products.

Globalisation facilitates the emergence of a global culture through advances in information technology. Information technologies like the internet, Web sites, Satellite, facilitate the transfer of information across nations and this makes the whole process of production cash-less enterprise.
Globalisation through information technology has transformed traditional societies to modern societies. Rural-urban differences are sharply broken down through the use of most modern information technologies like radio, television, etc. There are no longer any pure, undiluted traditional cultures. A global culture has therefore emerged. Physical movement across nations is also made easier because of improvement in transportation.

Scholars such as Stevens (2007), Ogbonnaya, (2011), Lere (2014), Collins (2015), Manolica and Roman (Undated) have however, criticized globalisation on several grounds. First and foremost, globalisation emanated from the North where the capitalist agencies like the World Bank and International Monetary Fund (IMF) supporting it are located. Its message of equal terms of trade and free movement of capital can be faulted or described as a fallacy because while the countries of the North talk of free trade they at the same time create barriers like the insistence on deregulation, removal of subsidies, liberalization, privatization, and devaluation of national currencies. These barriers benefit only the North.

Globalisation can also be said to be a process of westernization. It is a process of importing western cultures and values to other nations. Politically, globalisation can bring about the death of nation-states. Before the concept of globalisation, nations boasted of sovereign entities. Globalisation has broken this national or territorial entity or integrity. Decisions taken in other nations are influenced or subject to international censorship. There is now a global bloc that influences issues of development in other countries. In essence, the boundaries of independent nations are being eroded. The international bloc working side-by-side with regional, national blocs use certain values like democracy, respect to human rights as the standards to judge other countries. In fact, globalisation dictates how nations should behave. This attitude perpetuates rather than eliminate inequality.

Globalisation makes rich nations richer and the poor ones poorer. It is not a process aimed at addressing the poor status of less developed nations. For example, after the collapse of the Soviet Union, it was hoped that there would be significant commonality between the North and the South. But the continued existence of poverty in the South shows that globalisation has a hidden agenda. In fact, the subscription to western standards and norms has not helped 
countries of the South. Globalisation is a reenactment of the modernisation perspective. It is the 1950s and 1960s revisited under a new name.

\section{CONCLUSION}

This exposition has shown that colonialism laid the foundation for the categorization of the world. This was later given impetus by neo-colonialism, imperialism and the ideological war between the developed worlds. It has shown that the effect of the cold war was the shift of the world to a dualistic status- North and South. The exposition has however, noted that as the north and south dialogue was gaining momentum, globalization came onto the scene and pushed the world back to a one-world order; the global village.

\section{REFERENCES}

African Development Bank, 2012. Framework for Enhanced Engagement with Civil Society Organisations. Abidjan: AfDB

Albrow, M. and King, E., 1990. Globalization, Knowledge and Society. Sage

Collins Harper (ed) (undated). Definition of Colonialism. COBUILD Advanced English Dictionary. Harper

Collins Publication Online

Collins, M., 2015. The Pros and Cons of Globalization. http://onforb.es/lkirlmn

Evan, A., 2018. Why are Countries Classified as First, Second or Third World? www.history.com/news/why-arecountries-classified-as=first-second-orthird-world

Faal, Courtney 2009. The Partition of Africa. Blackpast www.blackpast.org/globalafrican-history/partition-africa

Gurtner, B., 2010. The Financial and Economic Crisis of Developing Countries. International Development Policy

Haughton, J. and Khander, S. R., 2009. A Handbook on Poverty. The International Bank for Reconstruction and Development. The World Bank
Horvath, R. J., 1972. A Definition of Colonialism. Current Anthropology 13(1) 45-57

Igboin, B. O., 2011. Colonialism and African Cultural Values. African Journal of History and Culture 3(6) 96-103.

Jezard, A., 2018. Who and what is Civil Society? World Economic Forum Agenda 23. www.weforum.org/agenda/2018/04/whatis-civil-society/

Kastrati, A., 2016. Civil Society from Historical to Contemporary Perspectives. European Journal of Multidisciplinary Studies 1(1) 64-68

Lere, Ishaku, 2014. Globalization and Development. The impact on Africa: A Political Economy Approach. International Journal of Sustainable Development. 7(9) 153-162

Longley, R., 2020. What is Imperialism? Definition and Historical Perspective. www.thoughtco.com/imperialismdefinition-4587402

Longley, R.(2021).What is Colonialism? Definition and Examples. www.thoughtco.com/colonialism-andexampless-5112779

Manolica, A and Roman T. (Undated). Globalization, Advantages and Disadvantages : from the Perspective of the Manufacturers. ES Working Papers

Muni, S. D., 1979. The third World: Concept and Controversies. Third World Quarterly Vol. $1 \mathrm{p} 121$

Nkwocha, A. E., 2008. Neo-colonialism and the Scandal of African Poverty: A Review. International Journal of Development and Management Review 3(1) 170-188

Ogbonnaya, I. D., 2011. Africa in the Age of Globalization. International Journal of Sociology and Anthropology 3(8) 295303 
Olasupo, O., Olaide, I. O. and ljeoma, E. O. C., 2017. Nationalism and Nationalists Agitation in Africa: The Nigerian Trajectory. The Review of Black Political Economy 44 pp261-283

Ongayo, A., 2008. Political Instability in Africa: where the Problem Lies and Alternative Perspectives.

The African Diaspora policy Centre, Amsterdam. A paper presented at the Symposium by Stichting national Erfgoed De werld Waganaingen 19/9/2008

Rahaman, S.MD, Yeazdani, R. and Mahmud, R., 2017. The untold History of Neocolonization in Africa 1960-2011. DOI:10.11648/j.history.20170501.12
Rodney, Walter, 1972. How Europe Underdeveloped Africa. Dar es Salaam; Tanzanian Publishing House

Sommer, Michael, 2011. Colonies-ColonisationColonialism: A Typological Reappraisal. Journal of Ancient West and East (AWE) Vol 10 pp 183- 193 DOI: 10. 2143/AWE. 10.0.2141818

Steven s, W., 2007. The Risks and Opportunities from Globalization. New Zealand treasury Working Paper) 7/05

Zajd, J., 2014. The Russian Revolution. in Ritzer, $G$ and Ryan, J. M. (eds) The wileyBlackwell Encyclopaedia of Globalization (online) 